\title{
WHY SO SILENT ON THE RIGHT TO SILENCE? Missing MATTERS IN THE REVIEW OF THE EVIDENCE ACT 2006
}

\author{
Elisabeth McDonald
}

\begin{abstract}
In this article I examine the scope and application of ss 32 and 33 of the Evidence Act 2006 (NZ) with reference to both the historical justification for the right to silence and the legislative history of these provisions. In considering the extent to which the sections do not reflect either the recommendations of the Law Commission in 1999, nor Parliamentary intent, I question why the sections were left out of the Commission's first statutory review of the Act in 2013. I conclude by suggesting that the right to silence should be the subject of informed public debate and raise some possible options for reform.
\end{abstract}

\section{INTRODUCTION}

The Law Commission has recently completed the first review of the Evidence Act 2006, as required by s 202 of the Act. ${ }^{1}$ The requirement that there be a regular review of the Act was added at Select Committee stage to enable "this very important area of the law to be kept up to date ... in a principled way." 2 Despite the statement made during the Third Reading of the Evidence Bill that $\mathrm{s}$ 202 would ensure that "[a]fter 5 years' operation, [the] legislation will go to the Law Commission for a very comprehensive review as to how it is working", 3 the Commission was of the opinion that $\mathrm{s}$ 202 does "not contemplate a first principles review", 4 but rather an "operational", 5 or "technical"

\footnotetext{
* Associate Professor, Faculty of Law, Victoria University of Wellington. My thanks go to Associate Professor Scott Optican for his helpful review on the aspects of this article that appear in my book Principles of Evidence in Criminal Cases (Brookers, Wellington, 2012), as well as my appreciation for the valuable comments made by the anonymous reviewer of this piece.

1 Law Commission, The 2013 Review of the Evidence Act 2006 (NZLC R127, 2013) [The 2013 Review].

2 (21 November 2006) 635 NZPD 6652 per Christopher Finlayson.

3 (23 November 2006) 635 NZPD 6802 per Christopher Finlayson (emphasis added).

4 The 2013 Review, above $\mathrm{n} 1$, at iv, [1.18] and [1.30].

$5 \quad$ At $i v$ and [1.30]
} 
review. ${ }^{6}$ Significantly the Law Commission stated that it was not "appropriate for the Law Commission to use the review as an opportunity to revisit policy decisions that were taken by the government ... throughout the legislative process" so that where "the legislative intent is clear and the Act is working as intended" the Commission has "not recommended change". 7

This approach allowed the Commission to categorise a number of matters as falling outside the scope of the review, including several issues relating to vulnerable witnesses. ${ }^{8}$ The Law Commission also concluded that recent proposals concerning the "right to silence" raised "fundamental policy matters that ... are outside the scope of this technical review". ${ }^{9}$ Consequently there is no discussion in the Report of the operation of ss 32 and 33, no recommendations for any reform and no suggested amendments to the wording of the sections even to clarify legislative intent. In my view, this omission is regrettable. It is not the case that s 32 is "working as intended" and could in fact be amended to ensure consistency with legislative intent. As observed by a number of commentators, there is public interest in the operation of the right to silence, ${ }^{10}$ and public discussion of the issue could in fact address misinformation about the scope of the right while legislative reform could helpfully clarify the current approach, without requiring revisiting any policy decisions.

In this article I first define the "right to silence" and outline the historical arguments in support of the right. I also discuss the current position in New Zealand, including an analysis of the operation of s 32. Drawing on recent case law, I make the argument that both ss 32 and 33 should at least be amended to clarify the current position and accurately reflect legislative intent. Ideally, however, there should be further public discussion of the issues for the purposes of education and the development of reform options.

\section{THE PRIVILEGE FOR A PERSON CHARGED WITH AN OFFENCE: THE "RIGHT TO SILENCE"}

In this Part I consider in what circumstances a person has a right to refuse to provide a police officer or a court with information on the grounds that disclosure of the information could expose

6 At [1.40].

7 At $[1.31]$.

8 At [1.42]-[1.52]. See further Elisabeth McDonald and Yvette Tinsley " "'The law as it should be' when prosecuting sexual offences: The contribution of legal academics to law reform: " (2013) 25 NZULR 758.

9 At $[1.40]$.

10 Bernard Robertson "The right to silence" [2012] NZLJ 222; Rt Hon E W Thomas "The Evidence Act 2006 and women" [2008] NZLJ 169; Elizabeth Binning "End the right to silence says QC" The New Zealand Herald (online ed, Auckland, 20 October 2006); Jeff Neems "Crimes victims slam right to silence" The Waikato Times (online ed, Hamilton, 21 September 2009). 
them to criminal liability. Although everyone has the right (subject to statutory abrogation) ${ }^{11}$ to refuse to answer questions from anyone, ${ }^{12}$ the situation is different once a person becomes a witness: $:^{13}$

In Court proceedings ... competent witnesses are ... compellable to give evidence - in the sense that if they refuse to answer questions they may be punished for contempt of court or prosecuted for some similar offence. But compellability is subject to some privilege that may apply; and there is a common law privilege ... that no witness is compellable to answer any question tending to incriminate himself. In the event of objection on that ground the trial judge has to rule on whether the question does have that tendency.

In relation to a person who has been charged with an offence the privilege applies both pre-trial (when being questioned by police) and at trial, and is recognised as part of the broader "right to silence". ${ }^{14}$ In the context of the Evidence Act 2006 (the Act), the privilege available for any other person applies only when they are a witness in a proceeding and on a question-by-question basis. In all situations, the privilege only applies when claimed (or exercised) by the person it belongs to (that is, the person who would risk prosecution as a result of disclosure). It can be waived by that person at any time - that is, the privilege protects only against compelled self-incrimination. Further, in relation to people other than an accused or a defendant, there need be no warning in advance of the risk of disclosure. ${ }^{15}$

Article 14(3)(g) of the International Covenant on Civil and Political Rights upholds the right to silence and in the context of criminal investigations largely encompasses the privilege against selfincrimination. ${ }^{16}$ It provides that every person facing a criminal charge shall have the right "[not] to

11 See for example, s 201 of the Fisheries Act 1996. A full list of statutory references was produced by the Law Commission The Privilege Against Self-Incrimination (NZLC PP25, 1996) at 140-144.

12 See the discussion of the right to freedom of expression as contained in s 14 of the New Zealand Bill of Rights Act 1990 in Andrew Butler and Petra Butler The New Zealand Bill of Rights Act: A Commentary (LexisNexis, Wellington, 2005) at [13.7.39].

13 Taylor v NZ Poultry Board [1984] 1 NZLR 394 (CA) at 398.

14 Section 23(4) of the New Zealand Bill of Rights Act 1990 states:

Everyone who is - (a) arrested; or (b) detained under any enactment - for any offence or suspected offence shall have the right to refrain from making any statement and to be informed of that right.

This language is consistent with a general right of silence, as opposed to a statement of the privilege that justifies a refusal to provide information only when disclosure may tend to incriminate the person claiming the privilege. See further Butler and Butler, above n 12, at [23.15].

15 D L Mathieson Cross on Evidence (8th ed, LexisNexis, Wellington, 2005) at [10.16]. But see s 62 of the Evidence Act 2006.

16 International Covenant on Civil and Political Rights 999 UNTS 171 (opened for signature 16 December 1966, entered into force 23 March 1976). The Covenant came into force in New Zealand on 28 March 1979. 
be compelled to testify against himself or to confess guilt". The privilege is reflected in s $25(\mathrm{~d})$ of the New Zealand Bill of Rights Act 1990, which is similarly worded and applies to those persons "charged with an offence".

This Part begins with an examination of the privilege as it applies to those charged with an offence. ${ }^{17}$ The much-debated issue in this area is what forensic use can fairly be made of a defendant's exercise of his or her right to silence, whether pre-trial or at trial. ${ }^{18}$ The contestability of any particular approach to the use of silence reflects the uncertain history and unclear rationale of the privilege. The suggested rationales are therefore now considered.

\section{A The Rationale for the Privilege}

The privilege against self-incrimination has a contested rationale. Some commentators are of the view that the privilege arose in the wave of opposition to two modes of questioning citizens in medieval England: questioning under the inquisitorial oath in the ecclesiastical courts, and incriminating questions in the Star Chamber. ${ }^{19}$ Although initially the privilege was confined to objections to the form of the oath in judicial proceedings, the common law came to recognise that a person should not be compelled to incriminate herself in the context of an extra-judicial interrogation. The right to silence is therefore arguably "bound up historically with a rejection of authoritarian, 'foreign' methods of criminal investigation, and consequently stands for the victory of freedom and justice over tyranny and despotism". ${ }^{20}$

There is also a lack of agreement as to what is a compelling rationale for preventing juries from drawing common-sense inferences from silence in appropriate cases: ${ }^{21}$

The privilege against self-incrimination stands in need of convincing justification. To be sure, there is no shortage of eloquent testimonials to the hallowed place of the right to remain silent in the pantheon of

17 Although the privilege applies at common law before a charge has been laid, in the context of considering the use of a defendant's silence as an evidentiary matter, this aspect of the privilege will not be explored here.

18 Law Commission Criminal Evidence: Police Questioning (NZLC PP21, 1992) at [6].

19 Law Commission The Privilege against Self-incrimination (NZLC PP25, 1996) at Chapter One; Bruce Robertson (ed) Adams on Criminal Law (online looseleaf ed, Brookers) at [ED20.07(8)]; C B Cato The Privilege Against Self-Incrimination and Reform of the Law and Practice of Police Interrogation (Legal Research Foundation, Auckland, 1985) at 6-9; Others maintain that the privilege arose in the 18th century with the development of the adversarial trial process - see John Langbein "The Historical Origins of the Privilege Against Self-Incrimination at Common Law" (1994) 92 Mich L Rev 1047 at 1066-1067.

20 Paul Roberts and Adrian Zuckerman Criminal Evidence (2nd ed, Oxford University Press, Oxford, 2010) at 538 .

21 Donald Dripps "Self-Incrimination and Self-Preservation: A Sceptical View" [1991] U Ill L Rev 329. 
Anglo-American liberties. But defenders of the privilege have yet to substantiate the misty rhetoric that cloaks the privilege in a haze of noble words.

In order to consider what contemporary rationale for the privilege exists it must be remembered that the current debate is not about whether there is a risk of severe physical or psychological coercion to answer questions should there be no "right to silence". Rather, framing the proper scope of the privilege requires consideration of the potential forensic implications of a defendant's silence. Paul Roberts and Adrian Zuckerman pose the relevant questions to consider in this way: ${ }^{22}$

\footnotetext{
When the accused chooses to exercise what is his undoubted right, to stay silent in the police station or at court, should he suffer any adverse evidential consequences? Silence might be costly for the accused, either because it triggers legal rules operating to his detriment, or, in a more diffuse and informal sense, if fact-finders adopt the commonly held view that, whereas innocence loudly proclaims itself, silence is guilty. An alternative way of formulating the central question would be to ask whether silence should be allowed to carry its ordinary probative force in criminal adjudication? Which in turn prompts supplementary questions requiring careful consideration: what exactly is the probative force of silence, and how should judges direct juries in relation to it? If untutored common sense reasoning regularly produces mistaken inferences, rules of evidence might be deployed to try to neutralize our natural tendency to equate silence with guilt.
}

If these are the correct questions to consider, which, if any, of the proposed rationales can appropriately inform the answers? In the words of the Law Commission during their original reform project: "The privilege has been claimed to uphold a number of interests, but no one interest predominates or applies in every situation in which the privilege can currently be claimed." 23

The concern about the "cruel trilemma" 24 - that is, it is cruel to compel a person to choose between the three perils of self-incrimination, perjury or contempt - is not a valid justification for the privilege as it is not clear why it is any less cruel to be incriminated by the evidence of another person than oneself. Further, ordinary witnesses are routinely faced with "cruel" choices - for example, whether to testify against a child or to refuse to do so. There is no general immunity ${ }^{25}$ "from having to make the choice between damaging a valued relationship" and being liable "for

22 Roberts and Zuckerman, above n 20, at 541.

23 Law Commission The Privilege against Self-incrimination (NZLC PP25, 1996) at 29.

24 At [57] - a phrase first used by Goldberg $\mathbf{J}$ in Murphy $v$ Waterfront Commission 378 US 52 (1964); see also Ian Dennis The Law of Evidence (4th ed, Sweet and Maxwell, London, 2010) at [5.49].

25 Although there may be a privilege attached to some aspects of the parent's evidence: Evidence Act 2006, s 69. 
perjury or contempt." 26 As the privilege stands in the way of having all the relevant information available to the fact-finder, personal hardship of itself cannot be a valid justification.

To the extent that the privilege protects privacy rights, in a way that subsequent exclusion of improperly obtained confessions cannot, it has a role to play at the investigation stage. However, privacy interests are not absolute, especially in relation to the prosecution of criminal conduct, which involves many invasions of privacy. ${ }^{27}$ It is therefore "difficult to see how drawing adverse inferences from silence somehow damages a special interest in privacy that is uniquely protected by the privilege against self-incrimination." 28

Other rationales for the privilege, such as the impact on the burden of proof and the quality of information available to the fact-finder, ${ }^{29}$ have also been rejected as reasons for not allowing the drawing of inferences from silence. ${ }^{30}$ The extent to which the privilege protects the innocent is also debatable, ${ }^{31}$ although the Law Commission took the qualified view that: ${ }^{32}$

[T] he privilege is not essential for all or most innocent witnesses, and it may not help the innocent more than the guilty. Rather, it can help some innocent people. The acquittal or vindication of those people is important, and the privilege's role in this respect should be preserved.

It seems likely that the contribution of the privilege to the avoidance of wrongful convictions (which would be a compelling rationale) is marginal in comparison to other procedural safeguards for a defendant. ${ }^{33}$ Such safeguards include those found in the Bill of Rights: the presumption of innocence, the right of confrontation and the right to counsel.

The Commission's final view was that the "main justification for the privilege is that it is an essential feature of our accusatorial system of criminal justice." 34 This view reflects both the longstanding historical role of the privilege and the direct relationship between the right to silence and

26 Roberts and Zuckerman, above n 20, at 551.

27 Dennis, above n 24, at [5.47].

28 Roberts and Zuckerman, above n 20, at 552.

29 Dennis, above n 24, at [5.44].

30 Law Commission The Privilege against Self-incrimination, above n 23, at [85] and [94]-[97].

31 Roberts and Zuckerman, above n 20, at 560.

32 Law Commission The Privilege against Self-incrimination, above n 23, at [97].

33 At [90]-[95]; Dennis, above n 24, at [5.43].

34 Law Commission Evidence: Reform of the Law (NZLC R55 - Volume 1, Wellington, 1999) at [275]. The same rationale is proposed by David Harvey "Speak and Be Not Silent: Recent Developments of the Privilege Against Self-incrimination" (1996) 4 Waikato L Rev 60 at 66. 
the presumption of innocence. Our accusatorial system values a fair contest between the parties, ${ }^{35}$ meaning the prosecution in an adversarial process should not be aided in their task by the defendant having to provide them with information when the State has significantly more resources. In the view of Ian Dennis, it is the prevention of the State's abuse of power which provides the most compelling rationale for the privilege: ${ }^{36}$

Prevention of abuse of state power is in turn referable to the overall aim of the law of evidence to

safeguard the legitimacy of criminal proceedings and of the verdict that is their outcome.

Roberts and Zuckerman challenge this claim and argue that the privilege should itself be justified as one of the features of an adversarial process: "[R]ather than deriving the privilege against self-incrimination from a conceptual analysis of adversarial procedure, adversarial features of criminal proceedings themselves require moral justification, just like the privilege [against selfincrimination]." ${ }^{37}$ Justification of the privilege on its own terms is, however, lacking.

Given the lack of a generally agreed and compelling rationale that would justify preventing the drawing of adverse inferences from exercising the privilege (that is, remaining silent), what remains to be discussed is whether and when any inference can legitimately be drawn. To the extent that the Act is not clear about this issue, it is the common law that provides some guidance.

\section{B Pre-trial Silence and Police Questioning}

As already stated, a person charged with an offence cannot be compelled to say anything in the course of "investigative questioning". ${ }^{38}$ Although very few people actually remain silent in response to questions asked during such a process, ${ }^{39}$ s 32 attempts to prevent the jury from using the

35 Law Commission The Privilege against Self-incrimination, above n 23, at [59].

36 See Dennis, above n 24, at [5.40].

37 Roberts and Zuckerman, above n 20, at 554.

38 This is defined in s 4 as

questioning in connection with the investigation of an offence or a possible offence by, or in the presence of, - (a) a member of the police; or (b) a person whose functions include the investigation of offences.

Although the section only applies in relation to "investigative questioning" - meaning an inference may be drawn from a defendant's silence in response to an allegation put to him by someone with whom he is "on even terms": see Bruce Robertson (ed) Adams on Criminal Law - Evidence (online looseleaf ed, Brookers) at [EA32.01(3)]; David Jones QC and Saaeda Verrall "Criminal - Admissibility and identification" in New Zealand Law Society Evidence Act 2006 Intensive (NZLS, Wellington, 2007) 131 at 139 .

39 Law Commission research on this point indicated 20 per cent of suspects exercise the right pre-trial: see Appendix 1 in Elisabeth McDonald Principles of Evidence in Criminal Cases (Brookers, Wellington, 2012) 325 [Principles]. 
defendant's silence in the face of such questioning as evidence of guilt. ${ }^{40}$ The reasons for this approach are noted in Cross on Evidence: $:^{41}$

The evidence against a person may be greatly strengthened by his or her failure to give an explanation, or by the inadequacy of the explanation which is given.

People react to charges in very different ways and this means that all inferences from silence must be made with caution. The silent party may have been confused or taken by surprise. He or she may have considered the allegation to be unworthy of an answer or may have wished to conceal matters which are irrelevant to the case before the Court. Reflections of this nature suggest that before a person's silence is allowed to count against him or her, the circumstances must have been such that an explanation was called for, and there must have been no apparent reason, apart from a consciousness of guilt, for its absence.

\section{Evidential use of pre-trial silence}

\section{Section 32 provides:}

Fact-finder not to be invited to infer guilt from defendant's silence before trial

(1) This section applies to a criminal proceeding in which it appears that the defendant failed -

(a) to answer a question put, or respond to a statement made, to the defendant in the course of investigative questioning before the trial; or

(b) to disclose a defence before trial.

(2) If subsection (1) applies, -

(a) no person may invite the fact-finder to draw an inference that the defendant is guilty from a failure of the kind described in subsection (1); and

(b) if the proceeding is with a jury, the Judge must direct the jury that it may not draw that inference from a failure of that kind.

(3) This section does not apply if the fact that the defendant did not answer a question put, or respond to a statement made, before the trial is a fact required to be proved in the proceeding.

Section 32(1)(a) refers to the common situation of a failure to respond to a question, but also a failure to respond to a statement. This means that, in contrast to some common law authorities, the

40 For a discussion of cases that consider whether the right to silence has been waived see Adams on Criminal Law (online looseleaf ed, Brookers) at [10.12.05].

41 Cross on Evidence, above n 15, at [2.16]. 
defendant's failure to respond to an allegation put to her should not be taken to mean she has accepted the allegation. ${ }^{42}$

The defendant's failure to disclose a defence before trial can also not result in an adverse inference (as to guilt) being drawn, although there are some statutory provisions that require disclosure in some circumstances (for example, a notice of alibi or the content of the evidence of a defence expert). ${ }^{43}$

Although s 32(2) contains a comprehensive attempt to prohibit the jury drawing an adverse inference from pre-trial silence, it says nothing about a judge sitting alone. The Law Commission had proposed that judges should also be prevented from drawing such an inference, ${ }^{44}$ and the rejection of this extension invites the argument that judges are able to use the fact of pre-trial silence to infer guilt. ${ }^{45}$ However, the Ministry's earlier advice indicated an intention to prevent all factfinders from drawing an inference "unfavourable to the defendant" from their pre-trial silence. ${ }^{46}$

The Commission's draft provision also prevented cross-examination by the prosecution of a defendant about the exercise of their pre-trial right to silence. ${ }^{47}$ This aspect of the Code was also omitted during the legislative process, with the result that evidence of a defendant's pre-trial silence may be offered by the prosecution, subject to relevance. ${ }^{48}$ Limited evidence of pre-trial silence may

42 Richard Mahoney and others The Evidence Act 2006: Act and Analysis (2nd ed, Brookers, Wellington, 2010) at [EV32.01(1)]

43 See Criminal Disclosure Act 2008, ss 22 and 23.

44 See the draft s 32(1) in Law Commission Evidence: Evidence Code and Commentary (NZLC R55 - Volume 2, 1999) at 90: "the fact-finder must not draw an inference that is unfavourable to the defendant".

45 Robertson, above n 19, at [EA32.02(2)].

46 Letter from Gordon Hook (Manager Criminal and International Law Team) to the Hon Phil Goff (Minister of Justice) "Evidence Bill: Differences between the Bill and Law Commission's Code" (8 February 2005) at $4:$

The Bill contains one clause intended to retain the current law. This clause prevents the fact-finder being invited to draw inferences of guilt form the fact that the defendant did not respond to official questioning before trial. Unfavourable inferences including inferences about the defendant's truthfulness can be made.

47 Law Commission Evidence: Evidence Code and Commentary, above n 44, at 90.

48 See Hitchinson v R [2010] NZCA 388 at [40]:

The drafting of the Act is somewhat obscure. Section 32 in itself does not rule evidence either admissible or inadmissible. Rather, what it does is prohibit the fact-finder drawing an inference that the defendant is guilty in certain circumstances. That prohibition would, however, in the circumstances where it applies, indirectly render the evidence of silence inadmissible, as such evidence has relevance only if it is available for the drawing of an inference of guilt. It would seem from the scheme of the Act that, where s 32 does not apply, the fact of silence and the question or 
well be permitted, for example, to report that the defendant was given an opportunity to make a statement to the police, but declined. In Osman $v R,{ }^{49}$ evidence was offered that the defendant interrupted the police officer who was giving him his rights to say that he would not answer any questions "unless it was to his lawyer or to the Judge". ${ }^{50}$ On appeal it was argued that the judge should have directed the jury that no inference of guilt could be taken from the failure to answer questions. The Court of Appeal held that the failure to do so, in the context of the case, did not result in a miscarriage of justice as the prosecution did not rely on the evidence to prove guilt or expressly seek to have the jury draw any inference from the defendant's silence: ${ }^{51}$

In the current case, the comment made by the [defendant], in reply to the question from the police

officer ... was essentially part of the narrative. No other basis was advanced for its admissibility. No

point was taken at the trial that the evidence was not relevant. It was merely referred to as contextual

material dealing with what the [defendant] said when he interrupted the constable during the

administration of his rights. In that sense, it merely framed his interaction with the police.

Although evidence of silence may not be treated as relevant to guilt (in the case of a jury trial at least), s 32 leaves open the possibility of evidence of a defendant's pre-trial silence being offered, including where it may be used to draw an inference about the defendant's veracity. ${ }^{52}$ At common law, the failure to disclose a defence before trial could be relied on to detract from the defendant's credibility when she testified in support of this defence. ${ }^{53}$ The Law Commission also proposed that the Act should prevent such a use. ${ }^{54}$

statement to which the silence relates are admissible pursuant to the general admissibility section, $\mathrm{s}$ 7 (original emphasis).

The Law Commission did consider that evidence of silence may be admissible, the issue being addressed was use: see Law Commission, above $\mathrm{n} 44$, at [C156].

49 Osman v R [2012] NZCA 32.

50 At [22].

51 At [30]. This can be compared to the outcome in Blair $v$ R [2012] NZCA 62 where the Court of Appeal held that a miscarriage of justice had occurred by the failure of the judge to give the warning in $\mathrm{s} 32(2)(\mathrm{b})$, given it was the judge that referred to the appellant's failure to respond to police questioning in his summing up: see [25]-[37].

52 See the argument made Richard Mahoney and others, above n 42, at EV 32.03, and adopted by the prosecution in Osman $v R$, above $\mathrm{n} 49$, at [27].

$53 \quad R v$ Foster [1955] NZLR 1194 (CA) at 1200; $R v$ Coombs [1983] NZLR 748 (CA) at 751.

54 Law Commission Evidence: Reform of the Law, above n 34, at [129]. 
The proposed change to the common law was rejected by Cabinet, following advice from the Ministry of Justice that the prosecutor should have the right to comment generally on the fact that a defence is raised for the first time at trial. ${ }^{55}$ The Associate Minister of Justice stated: ${ }^{56}$

I do not agree with the Law Commission's suggestion that this ban [on inviting a fact-finder to draw an inference of guilt] should be extended to include an inference about a defendant's truthfulness. This would preclude adverse comment on a defendant's failure to disclose a defence before trial. Nor do I agree with the Law Commission's suggestion that there should be a statutory ban on the fact-finder drawing inferences from a defendant's failure to respond to official questioning. This would invite delving into the workings of the jury.

If it is the case that a defendant's silence may be commented on and then used to infer they lack veracity, ${ }^{57}$ this would introduce a limited use rule contrary to the broad scheme of the Act. ${ }^{58}$ Further, if evidence of pre-trial silence is used for this purpose (as evidence "solely or mainly relevant to veracity" to use the words of s 40(4)), then the evidence would also be subject to the heightened relevance test in s 37 , and, if offered by the prosecution, subject to s 38 . In most circumstances it would be hard to argue that the fact of pre-trial silence would be substantially helpful in assessing the veracity of the defendant. Silence may have some weight, but not in all cases - less so when a defendant who elected not to make a statement is now willing to subject herself to cross-examination. As the veracity of a defendant who has remained silent pre-trial and at trial is not at issue, any evidence going to an assessment of their veracity is simply irrelevant. ${ }^{59}$

However, at common law a defendant's failure to disclose a defence could be used to draw an unfavourable inference about the defendant's credibility. As I have discussed elsewhere, ${ }^{60}$

55 Cabinet Paper "Evidence Bill: Paper 2: Admissibility of Evidence" (4 December 2002) CAB100/2002/1 at [33].

56 At [34].

57 See David Jones QC and Saaeda Verrall "Criminal - Admissibility and identification" in New Zealand Law Society Evidence Act 2006: Intensive (NZLS, Wellington, 2007) 131 at 140 where the authors agree that the legislative history of the section means it is

a moot point whether a party or the court is entitled to comment on pre-trial silence insofar as it may relate to other matters, such as the credibility of the accused or his or her truthfulness (which must relate to guilt or innocence in themselves).

58 See Hart $v$ R [2010] NZSC 91, [2011] 1 NZLR 1 at [55]:

The Act's general move towards simplification of the law of evidence would not be enhanced by reading in a limited use restriction when Parliament has not chosen to state that restriction expressly.

59 McDonald, Principles, above n 39, at 183.

60 At $168-170$ 
credibility encompasses both moral and probative credibility. It is only moral credibility that the veracity rules seek to regulate. It may well be argued that failure to offer a defence pre-trial, that is later offered in person at trial, is relevant only to probative credibility (reliability) and therefore outside of the veracity rules. In this sense the common law's approach would be preserved ${ }^{61}$ but only in the situation where a defendant who has remained silent pre-trial testifies at trial.

The common law distinction between an inference of guilt and damage to the defendant's credibility when asserting a defence is not without critics, however. In $E v R$, the Court of Appeal expressed the view that such a distinction "would test the skills of a philosopher". 62 The prosecution's suggested interpretation of s 32(2)(a), which did not need to be resolved on the facts of the case, ${ }^{63}$ was that it was intended to: ${ }^{64}$

maintain the distinction between prohibiting counsel inviting the jury to draw an inference that the defendant is guilty from a failure to make a statement to the police or disclose a defence before trial and the ability to make an adverse comment in the event that the defendant gives evidence containing an explanation which he could have provided earlier.

Such an approach would, as is acknowledged by the use of the word "maintain", preserve the common law position which the Law Commission did not favour - however the final drafting of the provision is "somewhat obscure". ${ }^{5}$ The Act does not include the Law Commission's proposed limits on the use of pre-trial silence and as a result leaves the rule of uncertain application in some contexts. As some use may be made of pre-trial silence, and a judge as fact-finder may use silence to infer guilt, the drafting of the section indicates ambivalence towards the use of silence consistent with the uncertainty about the appropriate purpose of the privilege. Although the Law Commission took a clear position about the use of silence, which they believed gave proper effect to the privilege, the proposals were not enacted. The government's response therefore indicates that pretrial silence does have some evidentiary value - unfortunately the Act has not clarified when it does so. ${ }^{66}$ Reforms in England and Wales have attempted to undertake this task, although with mixed

61 This is the interpretation also favoured in Don Mathieson QC (ed) Cross on Evidence (9th ed, LexisNexis, Wellington, 2013) at [EVA32.3].

$62 E(C A 727 / 09) v R[2010]$ NZCA 202 at [60]. See also the discussion in Blair $v$ R, above $\mathrm{n}$ 51, at [38]-[44].

63 The trial judge had directed the jury not to draw any inference from the defendant's failure pre-trial to refer to a matter raised in his defence: ibid at [62].

64 At [61].

65 Hitchinson $v$ R [2010] NZCA 388 at [40].

66 Sections 34-37 of the Criminal Justice and Public Order Act 1994 (E \& W) permit "such inferences from the failure as appear proper", but the Act provides no guidance on these matters. See further Rosemary Pattenden "Inferences from Silence" [1995] Crim LR 602. 
success and support. ${ }^{67}$ If some use is to be made of pre-trial silence, it seems appropriate that this possibility should be referred to in the caution given to suspects. ${ }^{6}$

If there is reconsideration of the policy underpinning s 32, it is worth exploring the adoption of a section similar in terms to 89 of the Uniform Evidence Act (Aust), given that the Law Commission originally drew heavily on the Australian reforms. The section provides:

Evidence of silence

(1) In a criminal proceeding, an inference unfavourable to a party must not be drawn from evidence that the party or another person failed or refused-

(a) to answer one or more questions; or

(b) to respond to a representation-

put or made to the party or other person by an investigating official who at that time was performing functions in connection with the investigation of the commission, or possible commission, of an offence.

(2) Evidence of that kind is not admissible if it can only be used to draw such an inference.

(3) Subsection (1) does not prevent use of the evidence to prove that the party or other person failed or refused to answer the question or to respond to the representation if the failure or refusal is a fact in issue in the proceeding.

(4) In this section, inference includes-

(a) an inference of consciousness of guilt; or

(b) an inference relevant to a party's credibility.

Section 89 bars any inferences "adverse to a party" and so prevents the fact-finder from using a person's silence on one occasion to infer that the person wanted to conceal their guilt or that a later account by that person lacks credibility. Section 89 is also wider in scope than s 32 as it applies to inference adverse to both the prosecution and the defence, an approach that would be welcomed by those who see the need for changes to the rules of evidence in relation to complainants in sexual

67 For commentary, mostly critical, see Di Birch "Suffering in Silence: A Cost-Benefit Analysis of Section 34 of the Criminal Justice and Public Order Act 1994" [1999] Crim LR 769; Ian Dennis "Silence in the Police Station: The Marginalisation of Section 34" [2002] Crim LR 25; Rosemary Pattenden "Silence: Lord Taylor's Legacy" (1998) 2 E and P 141; John Jackson "Silence and Proof: Extending the Boundaries of Criminal Proceedings in the United Kingdom" (2001) 5 E and P 145.

68 See Cross on Evidence, above n 61, [EVA32.3]. A provision which allows unfavourable inferences from pre-trial silence when a defendant has been given a "special caution" has recently been enacted in New South Wales: see Evidence Act 1995 (NSW), s 89A, as amended by Evidence Amendment (Evidence of Silence) Act 2013. 
cases. Section 89 does not bar inferences that are neutral or beneficial, but where there are no alternative uses of silence other than those barred by s 89(1), the evidence of silence is inadmissible. Evidence of the fact of pre-trial silence may well be simply irrelevant, unless offered to support an adverse inference, which is prohibited. ${ }^{69}$

\section{Silence at trial}

Consistent with the right to silence, a defendant cannot be compelled to be a witness by the prosecution or by a co-defendant. ${ }^{70}$ Once a defendant has elected to be a witness however, he or she cannot claim the privilege against self-incrimination in relation to the particular charge. ${ }^{71}$ If a defendant elects not to be a witness, the issue becomes, as with pre-trial silence, whether the factfinder can ever legitimately use this silence as part of the decision as to guilt.

Basing his argument on the rationale he supports, that is, prevention of abuse of state power, Dennis contrasts the forensic value of pre-trial silence with that of silence at trial: ${ }^{72}$

The curtailment of the right to silence in the police station is objectionable because of the risk of abuse of state power associated with custodial interrogation. Section 34 of the Criminal Justice and Public Order Act 1994 ought to be repealed as a matter of principle. The same objection does not hold for inferences from failure to testify at trial where the procedural context of the accused's silence is wholly different.

\section{The forensic implications of exercising the right not to give evidence at trial}

A defendant may choose not to testify because of a fear of exposing their guilt, but may also elect not to do so for fear of not making a good impression due to their appearance or through concern that a lack of confidence in responding to questions would reflect poorly on them. ${ }^{73}$

Whether any evidential use should be made of a defendant's silence at trial is a matter of continued debate. ${ }^{74}$ The issues are nicely raised in Adams on Criminal Law - Evidence in Criminal Cases: $::^{75}$

69 "[T]he questions which elicited no answer or a 'no comment' answer are inadmissible by operation of s 7 of the Evidence Act 2006 (no tendency to prove or disprove anything)": $R v$ Kingi HC Whangarei CRI-2010088-2617, 29 July 2011 at [40]. See also Richard Mahoney "Evidence" [2012] NZ L Rev 721 at 739-741.

70 See McDonald, Principles, above n 39, at 84-86.

71 See Evidence Act 2006, s 60(4)(c).

72 Dennis, above n 24, at [5.52].

73 See Donald Stevens "False Allegations of Sexual Offending" in New Zealand Law Society Criminal Law Symposium 2004 (NZLS, Wellington, 2004) 11 at 20.

74 Hammond $\mathrm{J}$ in $R v$ Haig (2006) $22 \mathrm{CRNZ} 814$ (CA) at [121] expressed the view that 
The failure of an accused to testify in answer to a prosecution case which has, independently, proved guilt beyond reasonable doubt adds nothing of relevance to the evidence, as the verdict is assured in any event. The crucial issue is confronted when the prosecution evidence itself is insufficient to prove guilt beyond reasonable doubt. The question is whether the failure of the accused to testify can add something to the prosecution case and nullify the reasonable doubt that otherwise existed.

The effect of using the accused's failure to testify as a potential means of destroying a reasonable doubt is an obvious weakening of the right to silence, and a subtle alteration of the traditional requirement of the burden of proof in criminal cases. The accused who is met with a prosecution case that has not proven guilt beyond reasonable doubt should confidently be able to choose not to give evidence. This confidence will not be possible if the failure to testify can then be used to convict.

Section 33 of the Act provides:

\section{Restrictions on comment on defendant's right of silence at trial}

In a criminal proceeding, no person other than the defendant or the defendant's counsel or the Judge may comment on the fact that the defendant did not give evidence at his or her trial.

This provision, which re-enacts s 366(1) of the Crimes Act 1961, leaves open the possibility of a judge commenting on a defendant's silence at trial. ${ }^{76}$ It does not prevent the judge noting that the defendant did not testify, or alerting the jury about the difference in weight to be accorded to an exculpatory pre-trial statement as opposed to courtroom evidence. ${ }^{77}$ It also does not prevent the judge drawing an adverse inference from a defendant's silence, or inviting the jury to do so. When it

[t]o say there has been a 'debate' over the right to silence in recent years would be to understate the force of the views held on both sides of this discourse.

The opinions of two judges writing extra-judicially 20 years ago illustrate the on-going nature of the issue: E W Thomas "The so-called right to silence" (1991) 14 NZULR 299; JB Robertson "Rights and responsibilities in the criminal justice system" (1992) 7 Otago LR 501.

75 Robertson (ed), above n 19, at [ED15.02(1)]. See also $R v$ Accused (CA78/88) [1988] 2 NZLR 385 (CA) at 391: The lack of testimony from a defendant cannot be used to "bolster an inadequate or marginal [prosecution] case."

76 If the prosecution, contrary to the section, does comment on the defendant's silence this may be rectified by an appropriate direction to the jury. See for example $E(C A 727 / 09) v R$ [2010] NZCA 202 at [62]; or such conduct may amount to a miscarriage of justice to be dealt with through the appeal process (see $R v C h e n$ [2009] NZCA 445, [2010] 2 NZLR 158 at [150]-[154]).

77 Davis $v R$ [2011] NZCA 380 at [35]. 
is considered appropriate for such inferences to be drawn is a matter of common law. ${ }^{78}$ In New Zealand, it is legitimate to direct the jury that an adverse inference may be drawn in the absence of a response to probative evidence offered by the prosecution. ${ }^{79}$ That is, "in the assessment process, in appropriate circumstances, the evidence tending to prove guilt may be accorded greater weight by an inference drawn from the absence of any answer or explanation from the accused." 80 The prohibition is therefore limited to a comment on the failure of the defendant to testify - it does not prevent comment on the failure of the defendant to call other evidence when such evidence might be expected.

The Court of Appeal in $R v$ Hines noted the logical relevance of the evidence of a defendant's silence when faced by a prima facie prosecution case: ${ }^{81}$

[There are] authorities which support the general proposition that where there is evidence, accepted as reliable, tending to show guilt an inference can be drawn from the withholding of any answer that such evidence may be more readily taken as proof to the required standard. That is common sense and exactly what occurs in all probability whether or not the subject of any express direction to the jury. In Haw Tua Tau v Public Prosecutor the Privy Council said:

English law has always recognised the right of the deciders of fact in a criminal trial to draw inferences from the failure of a defendant to exercise his right to give evidence and thereby submit himself to cross-examination. It would in any event be hopeless to expect jurors or judges, as reasonable men, to refrain from doing so. Although the Criminal Evidence Act 1898 prohibited the prosecution itself from inviting the jury to draw inferences from the accused's failure to testify in his own defence, it did not prohibit judges from commenting on such failure; very often the judge did comment and draw to the attention of the jury inferences that they might properly draw, if they thought fit, from the failure of the accused to go into the witness box to contradict the evidence of the prosecution on matters that were within his own knowledge or to displace a natural inference as to his mental attitude at the time of the alleged offence that, in the absence of some other explanation, would properly be drawn by any reasonable person from his conduct at that time.

There is no current consensus that the common law approach to the use that may be made of silence at trial is inappropriate. To the contrary, the Government did not accept the Law

78 Section 33 of the Evidence Act 2006 permits comment from the Judge or the defendant's counsel on the defendant's failure to testify during trial, however, it is silent on the circumstances in which such comment should made: see Richard Mahoney and others, above n 42, at [EV33.01].

$79 R v$ Gunthorp [2003] 2 NZLR 433 (CA); $R$ v Drain CA 249/94, 11 October 1994 at 3; Cross on Evidence, above n 61, [EVA33.3].

$80 R v$ Hines (1998) 16 CRNZ $236(\mathrm{CA})$ at 244.

81 At 244 (citations omitted). See also Purdie v Maxwell [1960] NZLR 599 (SC) at 605. 
Commission's recommendation ${ }^{82}$ that judges and juries should be prevented from drawing inferences from a defendant's silence at trial: ${ }^{83}$

I do not agree with the Law Commission's recommendation that Trompert v Police [[1985] 1 NZLR 357

(CA)] should be overturned so that failure to give evidence at trial may never be used to help establish guilt. I consider that such a blanket ban would be contrary to common sense and ineffective. Instead, I propose to retain section 366(1) of the Crimes Act 1961, which prohibits anyone, other than the defendant or judge, from commenting on the fact that the defendant refrained from giving evidence as a witness at trial.

It is also well accepted that in appropriate circumstances, the drawing of an adverse inference will not be inconsistent with the Bill of Rights. ${ }^{84}$ However, some are of the view that although such comment is possible, and the drawing of adverse inference permissible both by a judge sitting alone, and by a jury, "many judges never comment and others do so infrequently." 85

Legislative guidance as to when an adverse inference may be drawn may be helpful in order to clarify in advance of trial what may be the consequences for the defendant of electing not to be a witness. ${ }^{86}$ Such a legislative response may well result in a change to current practice: ${ }^{87}$

It is fair to say that the ... Trompert approach is applied fairly conservatively in New Zealand and judges seldom comment adversely when an accused has not given evidence. Conservative judicial practice in this respect has no doubt influenced the practice of the defence bar as to the calling of

82 Law Commission Evidence: Reform of the Law, above n 34, at [133]; see also s 34 of the draft Evidence Code in Law Commission Evidence: Evidence Code and Commentary, above n 44, at 94. The advice given to the Minister of Justice was that "in some circumstances such a blanket ban will be contrary to common sense and ineffectual": letter from Gordon Hook to the Hon Phil Goff, above n 46, at 5.

83 Cabinet Paper, above n 55, at [35].

84 See Butler and Butler, above $\mathrm{n} 14$, at [23.6]; see also $R v$ Drain, above $\mathrm{n} 79$, at 4 .

85 E W Thomas "The Evidence Act 2006 and women" [2008] NZLJ 169; $R$ v Haig (2006) 22 CRNZ 814 (CA) at [104(d)]. See also EW Thomas "Criminal Procedure and the Bill of Rights Act: A view from the bench" (paper presented at seminars held by the Legal Research Foundation, August 1992) at 55:

[There is] unwillingness of some Judges to comment at all, notwithstanding the express authorisation to do so in s 366(1). With many lawyers, the notion invades an article of faith, their inviolate conception of the right to silence. A combination of a frozen Hell and flying pigs will intervene before there is any change of heart on their part.

86 One of the criticisms made of the ability for a judge or jury to draw an adverse inference from silence is that the possibility does not form part of the Bill of Rights advice given to suspects. See also Elias CJ Practice Note: Police Questioning (s 30(6) of the Evidence Act 2006) [2007] 3 NZLR 297 discussed in McDonald, Principles, above n 39, at 236.

$87 R v$ Haig, above $\mathrm{n} 74$, at [104(d)]. 
defence evidence and this in turn reinforces the need for judicial caution as to what to make of a failure by a defendant to contradict the Crown case.

An adverse inference could be drawn where there might be additional facts, peculiarly within the knowledge of the defendant, which, if they existed, would explain or contradict prosecution evidence. ${ }^{88}$ An example of such facts in the context of sexual offending could be the defendant's perception of the events giving rise to a reasonable belief in consent. ${ }^{89}$ The rationale for allowing an inference to be drawn is that if such facts existed the defendant should proffer them as a witness, and therefore be subject to cross-examination to test that evidence or explore the existence of those facts: $:^{90}$

Silence certainly does not give rise to an inference of guilt: but, depending always on the particular facts, the prosecution evidence and natural inferences from it may more easily be accepted if not contradicted by evidence from the accused or other evidence called for the accused. In general, and subject again to the particular facts, the Judge is well entitled to explain this to the jury. It may well be desirable to do so to prevent the 'right to silence' from being over-exploited.

With regard to the current position, the Court of Appeal in $R v$ McCrae, ${ }^{91}$ summarised the decisions in which comment would be appropriate:

(a) where the accused has been given leave to cross-examine a complainant as to credibility, in circumstances where the accused could be expected to give evidence; 92

(b) when the accused relies on an exculpatory statement but gives no evidence to back up the statement; ${ }^{93}$

(c) when the accused through counsel has made a suggestion that someone else is responsible for the crime but gives no evidence in support of that proposition; ${ }^{94}$ and

(d) when an attempt is made by the accused to get his or her version of events before the jury by putting factual allegations to Crown witnesses and those allegations are not accepted by the witnesses. ${ }^{95}$

88 Roger Leng "Silence in court: From common sense to common law: Azzopardi" (2002) 6 E and P 62 at 65. See also Murray v Director of Public Prosecutions [1994] 1 WLR 1 (HL Northern Ireland).

89 Mike Redmayne "English Warnings" (2008) 30 Cardozo LR 1047 at 1075.

$90 R v$ McCarthy [1992] 2 NZLR 550 (CA) at 554.

$91 R v$ McCrae (1993) 10 CRNZ 61 (CA).

$92 R v G(1992) 8$ CRNZ 9 (CA).

93 R v Mou-Hi CA82/96, 13 August 1996.

$94 R v$ Accused (CA78/88) [1988] 2 NZLR 385 (CA) at 389; $R v$ Woodhouse CA117/06, 12 October 2006 at [18]. 
This type of approach could be codified as a reminder to judges that drawing an inference will be permissible in some cases. ${ }^{96}$ If there is a jury, they will need to be directed how, and in what circumstances, they may draw an adverse inference. In trials where a judge is sitting alone, the judge, when delivering reasons for the verdict, should include comment as to whether and how he or she used the fact of the defendant's silence at trial in reaching a guilty verdict. The content of a jury direction, which gained approval from the Court of Appeal as "entirely appropriate" and "orthodox" was delivered by the trial judge in $R v$ Woodhouse $:^{97}$

Now, it will occur to you that such evidence might have come from Mr Woodhouse but he has not given

it. Therefore the exercise of his right to silence may have an adverse effect on whether you think it reasonably possible that the defence contentions are right, which is to say it may affect the weight that you give the defence's suggestion. But I emphasise, you must not reason that because Mr Woodhouse gave no evidence, therefore he is guilty but his exercise of his right to silence may weigh against your accepting all or part of the defence submissions.

Aside from the fact that this approach discounts the view that silence at trial should never be used to support the prosecution case, there are difficulties with codifying a common law position that seems to rely on extremely fine distinctions: ${ }^{98}$

On the one hand, silence cannot perfect a faulty case but on the other hand it can be used in assessing the strength of the case and presumably whether it is faulty.

Whether such a direction really assists must be open to question, especially given the Court's acknowledgement that juries in all probability use an accused's silence in this way with or without a judicial direction.

Although there may perhaps be consensus as to when silence does mean something, without boldly claiming it may be used as a piece of circumstantial evidence, the Law Commission's original position has the appeal of clarity as it avoids the "fine distinctions". Such a position would not prevent a judge: 99

95 R v Allen CA274/04, 7 April 2005.

96 See Roberts and Zuckerman, above n 20, at 559; see also Mike Redmayne "English Warnings", above n 89.

$97 R v$ Woodhouse, above $\mathrm{n} 94$, at [16].

98 Cross on Evidence, above n 15, at [2.22]. See also at [2.20]:

There is, however, a tendency to hint at what is suspiciously like a distinction without a difference by speaking of the failure to give an explanation as something which adds weight to the opponent's evidence rather than as a fact which constitutes a separate item of circumstantial evidence against the party failing to explain.

99 Roberts and Zuckerman, above n 20, at 580. 
[making] the jury understand that an accused person is entitled to remain silent at trial, that refusal to testify is not tantamount to an admission of guilt, and that the accused's failure does not discharge jurors from their primary duty to weigh carefully all the evidence presented by both prosecution and defence before arriving at their verdict.

\section{CONCLUSION}

In the first review of the Evidence Act 2006, the Law Commission failed to make even "technical" changes to ss 32 and 33 of the Act, including those which could clarify the rules to achieve consistency with current practice and legislative intent. The Commission explained this omission on the basis that any work on these sections would potentially raise matters of policy which took the possible drafting changes outside the scope of the s 202 review. It is, however, possible to make the argument that the terms of s 202 are not so limited, especially when read alongside the statement in Parliament that the review should be "very comprehensive". Further, the Commission was not so constrained in other aspects of the review. The recommendation to repeal s 35 is clearly at odds with the Select Committee's approach to the admissibility of previous consistent statements, having made the decision to tighten the test first proposed by the Law Commission in its draft Code.

It would be a relatively straightforward exercise to amend s 32 to make it clear that a judge sitting alone is also not permitted to draw an adverse inference as to guilt from a defendant's pretrial silence, and to provide for the use of silence for the purposes of assessing testimonial reliability. Both these amendments would be consistent with governmental policy and legislative intent. Section 32 could also be amended to reflect the Law Commission's initial proposal, perhaps along the lines of s 89 of the Australian legislation. This could well be one outcome from further public discussion lead by the Law Commission, which may also have the desirable effect of creating an "informed" debate. ${ }^{100}$

Section 33 could also be amended to codify existing practice. This exercise would allow greater understanding of the forensic use of silence at trial, but could also provide a platform from which to sensibly debate reform options. It is hoped such debate will not be too far away. It will be another five years before the Law Commission is required by statute to again review the Evidence Act 2006. The on-going public interest surely requires a breaking of silence on the matter before then.

100 See Robertson, above n 10. 